\title{
Study on Management of World Cultural Heritage the Old Town of Lijiang Based on the Theory of Global Governance
}

\author{
Yang Li \\ Yunnan University of Finance and Economics, School of Public Management 650221 \\ (email:yanglikm2000@163.com)
}

\begin{abstract}
Under the circumstance of globalization, protection and management of world cultural heritage attract a lot of attention from the whole world as a controversial issue. There are various contradictions exist in the management process, in this paper, we based on global governance and also take global governance as theory perspective, focusing on the cultural dimension of global governance, the global recognization of world cultural heritage and the meeting point of both aspects, based on points mentioned, continue to study on global governance, after go through field research of The Old town of Lijiang, analyze the cultural value of Lijiang and what does it affect the world, more importantly, in order to make further studies on the more innovative mode to protect and management The Old Town of Lijiang, details such as the management and protection status of the Old Town and current issues of the Old Town are needed.
\end{abstract}

Keywords: World heritage; governance; management

\section{Introduction}

On November 17th 1972, Conference of UNESCO was held in Paris. The conference passed "Convention Concerning the Protection of the World Cultural and Natural Heritage", also called "The World Heritage Convention" for short. Administration of "The World Heritage Convention" is the UN World Heritage Committee, which was founded in 1976, the "World Heritage List" was built in the same year. The main contents of the "World Heritage Convention": defining the cultural and natural heritage and qualification to be included in the "World Heritage List "; clearing responsibilities for treaty powers to identify potential heritage projects, as well as functions while they protect these heritages; elaborating functions of World Heritage Committee; explaining how to use and manage the World Heritage Fund. According to the "World Heritage Convention", the heritage sites which visited and solemnly certified by experts are called "World Heritage" no matter natural heritage, cultural heritage or both combined. World Heritages are valuable resources for all mankind and they are non- renewable, therefore, one of the important purposes of declaring World Heritage Site is to make people understand the value of world heritages in order to protect them, to use them properly, and to create a colorful world for all of us.

Although the Old Town LIjiang is just a member of World Heritage list, but it is showing us a wealth of experience in the protection and management of cultural heritage, this paper will summarize the theoretical perspective of governance protection management model of the Old Town Lijiang, and also provide an example for the protection and management of World Heritage sites around the world.

\section{The Analysis of Applicability of Global}

Governance Theory to the Study of Management of World Cultural Heritage

The applicability of global governance theory to the analysis of management of world cultural heritage protection lies in the global identity of the value of world cultural heritage, and the coincidence with the cultural dimension of global governance theory. 


\subsection{The definition, subject, contents and cultural dimension of global governance}

2.1.1 The definition of global governance

At present, there is no agreement on the definition of global governance in the academic field. The scholars are making analysis of global governance from different perspectives.

The committee of global governance holds the view that global governance is a sum of dealing with common affairs with all kinds of individuals, teams, in public or individual. This is a continuous process, through which all the conflicts and benefits can be reconciled and the cooperative measures can be taken. This process includes authorizing recognized teams and authorities the power of compulsory execution, and achieving the agreement which people or group agree with or accord with their benefits. David Herder thinks that, global governance means not only the formal system, the cooperation between state institutions and government, making rules and standards of managing the world order. But also other organizations and pressure groups' pursue of targets which will influence the transnational rules and authority systems from multinational companies, transnational social movements, to many NGOs. Chinese scholar Yu Keping thinks global governance mainly includes the subject, contents, means and values of global governance.

\subsubsection{The Multiple Subject of Global Governance}

According to the definition of global governance above, we can analyze that global governance is a governance of multiple subjects. The multiple subjects include countries, international organizations between governments, NGO, social movements, enterprises, transnational companies, and people in any countries, which will have an influence on global governance. Because of the difference between the status and effects of the subjects, there should be a certain principle and sequence between multiple subjects in order to avoid or reduce the conflicts among subjects. In the process of global governance, the relations between multiple subjects should be defined.

\subsubsection{The Contents of Global Governance}

The contents of global governance include economic development, environment, immigration, infectious disease, and all kinds of international conflicts, which should be dealt with in a way of global governance. As a result, it is unrealistic and difficult to operate to deal with the global issues in all fields with the same international mechanism. The formation of an international mechanism is a long-term interactive process, a process of bargaining, and a result of gaming between different international subjects.

2.1.4 The cultural dimension of global governance

Through the analysis of the subjects and contents of global governance, we can see the common cultural value idea achieved by multiple governance subjects is the basis of global governance; the origin and development have its cultural source, with its limitation in cultural difference and conflicts. The cultural elements of the origin of global governance, and the cultural factors of the dilemma in global governance are considered as two major elements to study the cultural dimension of global governance.

\subsection{The common value of world cultural heritage}

According to the first article in Convention of protecting world cultural heritage, world cultural heritage include:

Firstly, cultural relics: from the perspective of history, art, science, the buildings, sculptures, paintings with extraordinary universal values, the components, structures, inscription, caves, residence, 
and synthesis of all kinds of cultural relics with archaeological meanings.

Secondly, building group: from the perspective of history, art, science, in the aspect of building types, uniformity, and the combination with environmental landscape, single or related building group with extraordinary universal values.

Thirdly, sites: from the perspective of history, aesthetics, and anthropology, the man-made project, or the common masterpiece of both human and nature and archaeological sites with extraordinary universal values.

According to the instruction of Convention of protecting world cultural heritage, the extraordinary universal values refer to the highest level of importance of culture or natural heritage exceeding the national limit, and to the present and future of human.

2.3 Agreement between the universal value of world cultural heritage and cultural dimension of global governance

Convention of protecting world cultural heritage's discussion on the extraordinary universal values of world cultural heritage is helpful to the establishment of human universal values, which is beneficial to the connection between protection of cultural heritage with the UNESCO policies, promotes the interaction and reform of the protective ideas, and provides chances for cultural discussion over protecting problems, finally bring about the new understanding of protective methods. High contracting parties make their cultural attributes understood through international dialogue, which gives more standard and rich meaning to its culture and gives play to the creativity of cultural diversity and develops its own culture. The heritage sites can promote the economic and cultural prosperity to the contracting parties, and become the source of sustainable development.

Above all, Convention interacts with the new time, and makes communication with culture. The related parties can gain consensus through consultation, and make reflections on heritage, value, culture, nature, human existence and development. This is also the practical basis for global governance.

\section{The Outstanding Universal Value, Conservation Status and Existing Problem of Lijiang}

Old Town of Lijiang is in northwest of Yunnan, China. It is located in the middle reaches of Jinsha River, and named as its beauty of Jinsha River. Its geographic coordinates is east longitude $100^{\circ} 14^{\prime}$, north latitude $26^{\circ} 52^{\prime}$. Its altitude is more than 2,400 meters. It is located in southeast edge of the Tibetan Plateau and Hengduan mountains distribution zone. Its scopes include Dayan Old Town (including Black Dragon Pool), Baisha and Shuhe residential buildings. There are more than 6000 original inhabitants and 25,000 populations; Naxi people occupy 73.86 percentage of population.

\subsection{Outstanding Universal Value of Lijiang}

Outstanding Universal Value of Lijiang is reflected in two parts: material culture and intangible cultural heritage. Both of them are caused by traditional culture of Lijiang.

\subsubsection{Outstanding Universal Value of Lijiang's} Intangible Cultural Heritage

Outstanding Universal Value of Lijiang's Intangible Cultural Heritage is mainly reflected in layout of Old Town and residential buildings.

The uniqueness of the Old Town layout is manifested in two aspects, which are site selection and layout. Lijiang Ancient City is located in southeast edge of the Tibetan Plateau and Hengduan mountains distribution zone. The buildings, strewn at random 
discretion, are built along the mountain that also makes house and yard full of sunshine. The address selection is with high science because it makes full use of the terrain and the microclimate condition that is formed by the natural environment. It embodies the concept of harmony between human and nature. Ancient Residential buildings are based on the hill at the back and overlooking the steam. In additional, they are combinations that based on the terrain. Houses here are constructed by the timber frame, cob wall, and tile roof. They are built with clever combination with slope, and drainage utilization instead of subverting them. Local-style dwelling houses are simple but vivid.

3.1.2 The Outstanding Universal Value of Nonmaterial Cultural Heritage

The outstanding universal value of non-material cultural heritage of Lijiang ancient city mainly manifest in: Dongba culture, including the Dongba text, Dongba classics, Dongba painting, Dongba dance and music. Dongba culture is a kind of religious culture, and it also is ancient Naxi culture. Dongba culture is named by Dongba religion. It is one of important contents of Naxi culture by passing from generation to generation.

\subsection{The current situation of management of ancient cities}

Since Lijiang ancient city were listed as world cultural heritage, it has been put under public attention. Although there are some disputes over the developmental mode of ancient cities, it has directly influenced the protection and development of world cultural heritage.

\subsubsection{The subject of management}

There are five major parties led by the government to manage the Old Town Of Lijiang, first of all, the world heritage organization; authority of cncient city protection; cultural industry association in ancient city; cultural enterprise; and the inheritor of national culture.

3.2.2 The means of ancient city management

There are several of means of the ancient city management such as the Legal system; Establishing the monitoring system over heritage; the establishing of system of publicity and education; and the most importantly, the protection of international cooperation.

\subsection{The main problems existing in the management of Lijiang ancient city}

Although great achievement has been achieved in the protection and management of ancient city, there are still some difficulties and problems existing.

3.3.1 The cultivation of outstanding cultural inheritors and folk artists is extremely urgent.

At present, as the death and aging of old Dongba, folk artists, craftsman, the folk cultural elite is increasingly less. Only by cultivating folk cultural elites can the culture be inherited and the charm of Lijiang culture can be kept.

3.3.2 The lack of capital in the protection of ancient city

In order to protect the authenticity and integrity of heritage, since 2001, the tourists in ancient city should be levied the maintenance charge and the amount of levying has reached 0.9 billion. However, from 2002 till now, the capital invested in the protection of world heritage of Lijiang has reached 1.4 billion, with a following investment of 3 to 5 billion yuan in the future to finish the environmental renovation and change of the ancient city and the surroundings.

3.3.3 The loss of indigenous people in ancient city

Lijiang ancient city is the cultural accumulation of Naxi nationality of thousands of years, which is the 
collective manifestation of specific life style and creativity of Naxi. As the indigenous people of ancient city, Naxi has been living in the traditional cultural state under the cultural influence of traditional culture, together with the advantage of language, which is the reason for inheriting traditional culture. With the development of tourism in ancient city, and the flooding of external population, the indigenous people immigrate externally in a large amount, which will seriously influence the protection of national culture. Future more, the buildings with historical significance are desperately required to be repaired.

\section{The solution of perfecting Lijiang management from the perspective of global governance}

\subsection{Setting up the idea of global governance}

The new trend of protection of world culture refers to distributing the consciousness of cultural relic protection to each people. The government should change from the responsible role for the heavy protection of cultural relics to a supervisor with a macroscopic planning, and encourages social organizations and public participation into the protection of world cultural heritage.

4.2 Government should play the dominate role in strengthening the cooperation with NGOs to deal with the problem of lack of capital.

The multiple subjects of governance have played an important role in protecting ancient city. The government should play the dominant role and communicates actively with the multiple subjects, makes cooperation in many ways, establishes scientific and reasonable supporting system of capital, in order to provide strong economic support for the effective protection and management of relics, and realize the scientific protection and development of relics.

\subsection{Retain the indigenous people from the perspective of community governance}

Regard ancient city and the surrounding residence as the synthetic community, thus resulting in the common regional identity, value, related benefits and close communication of the residence inside and outside ancient city. As a result, on the one hand, regard the synthetic community ad an important stakeholder and manager of the management of world relics, and encourage community participation into the management, finally forming natural inheriting of traditional culture; on the other hand, form a excellent mechanism of ancient city and surrounding residence in order to strengthen the feeling of ancient city and decrease the speed of external migration and encourage the management of ancient city of external immigrate which can sustain the national characteristics.

\subsection{Establish the cultivating system of cultural inheritors and folk artists}

Governance is s systematic work; as a result, we should include the cultivation of inheritors and folk artists into the development of tourism products, and embodies the cultural value inherited by cultural inheritors and folk artists. Finally the inheriting of culture can be realized.

\section{Conclusion}

We can conclude as follows from the above research: Analyzing the protection of world cultural heritage with the global governance theory aims at providing the global perspective, and promoting an idea participated by different subjects, and the idea of fairness, justice, harmony. The consensus produced under the background of culture integration is the positive result of multicultural communication. Global governance should based on the common cultural value, and depend on cultural communication 
to break through dilemma and limitation in the process of managing public affairs and search the developmental motivation form cultural consensus.

Global governance breaks through the traditional dichotomous approach mode of thinking theoretically, which refers to political country and civil society, government and market, sovereign country and international organization, regards the process of dealing with international affairs as the process of cooperation, and establishes a cooperative mechanism of managing international affairs. Global governance is not establishing national government or international government, but cooperating among international subjects in the global scope. The thesis is based on this idea of regarding the dealing with the international affairs as cooperative management, and be applied into the research of protection of world cultural relics in order to explore the creative managing mode used in protecting common wealth of human.

Under the present condition of urbanization, due to the unconsciousness of the value of human cultural relics, especially the aesthetic values of old building, many ancient cities are gradually vanishing in the construction of urbanization. Sixty years ago, Chinese famous architect, Liang Sicheng had wailed for the disappear of ancient Beijing city. The study on the management of Lijiang ancient city can on the one side increase one's consciousness of protecting world relics, on the other hide, the aim of management of protection of world cultural heritage is to apply, and search for the way of protection in use.

\section{References:}

[1] Wal Karson, Shilidart Lanfarl, Our Global Neighborhood---the report of Global governance Committee[M] Beijing: China Foreign Translation Press 1995.2

[2] Davis Herder, Global Revolution: Politics, Economics and Culture in the time of Globalization[M] Beijing: Social Science Document Press, 2001.

[3]Yu Keping, Globalization: global governance $\{\mathrm{M}\}$ Beijing: Social Science Document Press, 2003.

[4]Ren Binqiang Globalization, National Sovereignty, and Public policies Peking University Press 2007 edition Page 49-73

[5] America $\}$ David Osborne, Ted Blur. Reform of government: how the enterprise spirit can reform the public department[M] Shanghai: Shanghai Translation Press, 2008 edition

[6] Yang Guifang Ding Wenjie Ge Shaode the study of world cultural relics-Lijiang' $\mathrm{s}$ tourism environment[M] Beijing: Nationality Press, 2005 edition

[7] Shi Chenxuan the evolution of evaluation standards of extraordinary universal values of world cultural relics[J] landscape architecture 2012(2)

[8] Shen Suyan, the study of the willing of payment of tourists in the protection of world cultural heritage[J] Journal of North-western agricultural technology ( social science) 2013(03)

[9] Gu Jiang; Wu Jiangjun the influential effect of world cultural relics on Chinese tourism 【J】 Nanjing Social science 2012 (7)

[10] Wang Xiaoling the study of resource management of Summer Palace as world cultural relics[J] Chinese garden 2013(1) 